\title{
Facile biogenic synthesis of silver nanoparticles (AgNPs) by Citrus grandis (L.) Osbeck fruit extract with excellent antimicrobial potential against plant pathogens
}

\author{
Bhaskarjyoti Gogoi $^{1} \cdot$ Rupesh Kumar $^{1} \cdot$ Jnanendra Upadhyay $^{2} \cdot$ Debajit Borah $^{1}$
}

Received: 15 April 2020 / Accepted: 16 September 2020 / Published online: 23 September 2020

(c) Springer Nature Switzerland AG 2020

\begin{abstract}
Biogenic silver nanoparticles (AgNPs) were synthesized by using Citrus grandis (L.) Osbeck fruit extract through a simple one step method by reducing silver nitrate $\left(\mathrm{AgNO}_{3}\right)$ at room temperature. Citrus grandis (L.) Osbeck is an indigenously available edible citrus fruit tree in Northeast India and sub-Himalayan foot hills. Formation of AgNPs were confirmed primarily by UV-Vis spectrophotometer and extensively characterized by TEM and XRD. The plasmon resonance at $435 \mathrm{~nm}$ confirmed the formation of AgNPs and TEM analysis showed AgNPs with average size of $11 \pm 3.57 \mathrm{~nm}$. XRD analysis showed crystalline nature of the Ag NPs with fcc lattice points attributed to (111), (200), (222) and (311) planes. The AgNPs showed excellent antimicrobial activities against both Gram positive (Bacillus cereus) and negative (Pseudomonas syringae pv. syringae) plant pathogens. It exerted MIC value of 20 and $30 \mu \mathrm{g} / \mathrm{mL}$, respectively against $B$. cereus and $P$. syringae pv. Syringae, whereas $\mathrm{MBC}$ value of 70 and $80 \mu \mathrm{g} / \mathrm{mL}$ were observed against $B$. cereus and $P$ syringae pv. Syringae, respectively. The Ag NPs showed no considerable cytotoxicity against murine macrophage RAW264.7 cell line which indicates its further possible application for animal model trial.
\end{abstract}

Keywords Green synthesis · Citrus grandis · Plant pathogens · Pseudomonas syringae pv. syringae · Bacillus cereus

\section{Introduction}

Metal nanoparticles such as gold and silver have found importance in the field of nanotechnology not only due to their unique optical, electrical, and photothermal properties but also for excellent therapeutic application as antimicrobial agent [1, 2]. Typically, synthesis of nanoparticles is carried out by physical or chemical routes, which are not environment friendly. Therefore green synthesis of metal nanoparticles became an important area of research in recent years in the field of nanobiotechnology which includes the use of plant extracts, animal proteins, agro-wastes, enzymes, pigments, bacteria, fungi and even viruses. Nevertheless the use of plant based synthesis of NPs are most preferable due to its advantages over the conventional methods of handling difficulties in culturing and maintaining microbial cells [3-7].

Citrus grandis L. Osbeck is an edible fruiting plant species widely available throughout Northeast India. The food and medicinal value of this plant species is widely studied by researchers but is not exploited for its potential application as a reducing and stabilizing agent in green chemistry. Citrus grandis L. Osbeck, locally known as Robab Tenga in Assam (Pomelo in English) belongs to the family Rutaceae, which is widely cultivated in Northeast India and also readily available in sub-Himalayan foothills. Along with the

Bhaskarjyoti Gogoi and Debajit Borah contributed equally.

Bhaskarjyoti Gogoi, gogoi.bhaskar2608@gmail.com; $₫$ Debajit Borah, dborah89@gmail.com |'Department of Biotechnology, Royal Global University, Guwahati 781035, India. ${ }^{2}$ Department of Physics, Dakshin Kamrup College, Guwahati 781125, India. 
food values, it also has some medicinal properties with antioxidant activity and higher flavonoid, ascorbic acid and polyphenol contents, which may play crucial role in reducing metal salts into stable metal nanoparticles [8-11]. On the other hand, growing antibiotic resistance among microbes due to their frequent use emerges itself as an issue of global concern. Noble metals (i.e. Au, Ti, Pt, Pd, Ag etc.) are well established as potent antimicrobials against both bacteria such as Staphylococcus aureus, Escherichia coli, Pseudomonas aeruginosa, Klebsiella pneumoniae, Salmonella typhimurium among others and fungi which includes Aspergillus niger, Rhizoctonia solani, Candida etc. $[6,12-16]$. Besides, AgNPs are least explored in terms of their application against plant pathogens such as $P$. syringae pv. Syringae which is responsible for causing lesions in fruit and leaf, gummosis in stems, blossom blast and spur dieback etc. [17-23]. Pseudomonas syringae pv. syringae is a Gram negative bacteria which is one of the most common plant pathogen in Europe and Asia which causes death of both young and older fruiting trees [21-23]. On the other hand, Bacillus cereus is responsible for causing fire blight disease in plants [24]. Therefore, in the present study, a novel one step, cost effective approach for the biosynthesis of AgNPs using Citrus grandis L. Osbeck fruit extract at room temperature is reported. Further, antimicrobial activity against plant pathogens and cytotoxicity assay of the Ag NPs was also explored.

\section{Experimental details: materials and methods}

Silver nitrate was purchased from SRL, India Ltd. Fresh pomelo was collected from local market of Namrup $\left(27.1836^{\circ} \mathrm{N}, 95.3469^{\circ} \mathrm{E}\right)$, Assam of India and was identified by the taxonomist of Department of Botany, Royal Global University, Assam. Animal tissue culture materials were obtained from Gibco-BRL, Life Technologies Inc., Gaithersburg, MD, 20884-9980, USA and Sigma Aldrich, St. Louis, MO, USA. MTT was procured from Himedia, India Ltd.

\subsection{Preparation of the fruit extract}

The fruit juice was extracted and filtered through muslin cloth. These were then centrifuged at $8000 \mathrm{rpm}$ for $10 \mathrm{~min}$ at room temperature. The supernatant was collected and used as extract for the synthesis of AgNPs.

\subsection{Biosynthesis of silver nanoparticles (Ag NPs)}

Exactly $1 \mathrm{mM}$ of $\mathrm{AgNO}_{3}$ solution in deionised water was mixed with the fruit extract in a ratio of 2:1 and was stirred with a magnetic stirrer vigorously for $20 \mathrm{~min}$ in presence of sunlight. The change in color of the solutions as a result of bioreduction was monitored.

\subsection{Characterization of Ag NPs}

The preliminary confirmation for the synthesized AgNPs was done by analyzing the Plasmon resonance within the range of 200-800 $\mathrm{nm}$ with the help of UV-Vis spectrophotometer at an interval of $5 \mathrm{~min}$ for $20 \mathrm{~min}$. The standard $\mathrm{AgNO}_{3}$ solution used for the synthesis of AgNPs was analyzed within the same range of wave length.

Morphological analysis of the AgNPs was performed on a 200 kV HRTEM model JOEL JSM 6390 LV while X-ray diffraction analysis was conducted on Rigaku miniflex X-ray diffractometer.

\subsection{Antimicrobial assay}

Overnight cultures of Pseudomonas syringae pv. syringae and Bacillus cereus adjusted to O.D. ${ }_{600}=1.0$ were spread plated on Mueller-Hinton (MH) agar and agar wells were made by using a cork borer. The respective wells were then individually loaded with $100 \mu \mathrm{L}$ of AgNPs (100 $\mu \mathrm{g} /$ $\mathrm{mL}), \mathrm{AgNO}_{3}$ and fruit juice separately, followed by $24 \mathrm{~h}$ of incubation at $37^{\circ} \mathrm{C}$. Appearance of zone of inhibition around the well confirms the antimicrobial effects of the respective solutions, while the zone of inhibition around each of the wells was also recorded.

\subsection{Determination of minimal inhibitory concentration (MIC) and minimal bactericidal concentration (MBC)}

MIC and MBC of Ag NPs was evaluated by standard broth dilution method [25]. Briefly, AgNPs were added to individual test tubes at a final concentration of $10,20,30, \ldots 80 \mu \mathrm{g} /$ $\mathrm{mL}$ containing overnight cultures of Pseudomonas syrin-

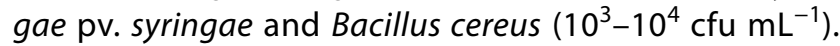
Bacterial growth was measured in terms of absorbance at $600 \mathrm{~nm}$ using UV-Vis spectrophotometer at an interval of $1 \mathrm{~h}$ till 6 th $\mathrm{h}$ after incubation at $37^{\circ} \mathrm{C}$.

\subsection{Cytotoxicity assay of Ag NPs}

In-vitro cytotoxicity assay of AgNPs were carried out by MTT [3-(4,5-dimethylthiazol-2-yl)-2,5-diphenyltetrazolium bromide] method on murine macrophage RAW264.7 cell line. In brief, approximately $1 \times 10^{4}$ cells $/ \mathrm{mL}$ were cultured in DMEM media supplemented with $2 \mathrm{mM}$ L-glutamine, $1 \mathrm{mM}$ sodium pyruvate, $10 \% \mathrm{FBS}$ and penicillin (100 U/ $\mathrm{mL})$, streptomycin $(10 \mu \mathrm{g} / \mathrm{mL})$ and allowed to incubate at $37^{\circ} \mathrm{C}$ in a humidified $5 \% \mathrm{CO}_{2}$ environment. The cells were then treated with Ag NPs at different concentrations $(0,20$, 
$40, \ldots 160 \mu \mathrm{g} / \mathrm{mL}$ ) in separate tubes after achieving $80 \%$ cell confluence. These were then incubated for $24 \mathrm{~h}$ followed by addition of MTT ( $5 \mathrm{mg} / \mathrm{mL}$ in PBS) and again incubated for $5 \mathrm{~h}$. Formation of farmazone complex by viable cells were monitored by taking the absorbance at $570 \mathrm{~nm}$ [25]. The percentage cell viability of the treated cells (with AgNPs) was compared to the control cells (without treatment with AgNPs). The flow chat of fruit extraction process, AgNPs synthesis, characterization and biological applications is depicted in Fig. 1.

\subsection{Statistical analysis}

All the experiments were performed in triplicate and the results were expressed in mean \pm SD Student's $t$ test was performed to see the statistical significance of the results using Graphpad ${ }^{\mathrm{TM}}$ online statistical tool.

\section{Results and discussion}

\subsection{UV-Visible spectroscopic analysis}

The UV-Visible spectra of silver nanoparticles synthesized by the reduction of $\mathrm{AgNO}_{3}$ with Citrus grandis (L.) Osbeck fruit juice is depicted in Fig. 2. From the figure, it is clear that AgNPs showed absorption maxima around $435 \mathrm{~nm}$ due to characteristic surface plasmon resonance (SPR) [26]. The peak was found to be prominent with the increase in time of reaction and a distinct hump was observed after 20 min of reaction which indicates the formation of stable AgNPs after 20 min. However, $\mathrm{AgNO}_{3}$ showed no distinct peak within this spectral range.

The plant part used in this study as a reducing agent for the synthesis of AgNPs was reported as a rich source of natural antioxidants, flavonoid, ascorbic acid, polyphenols, etc. in previous literatures which may be responsible for

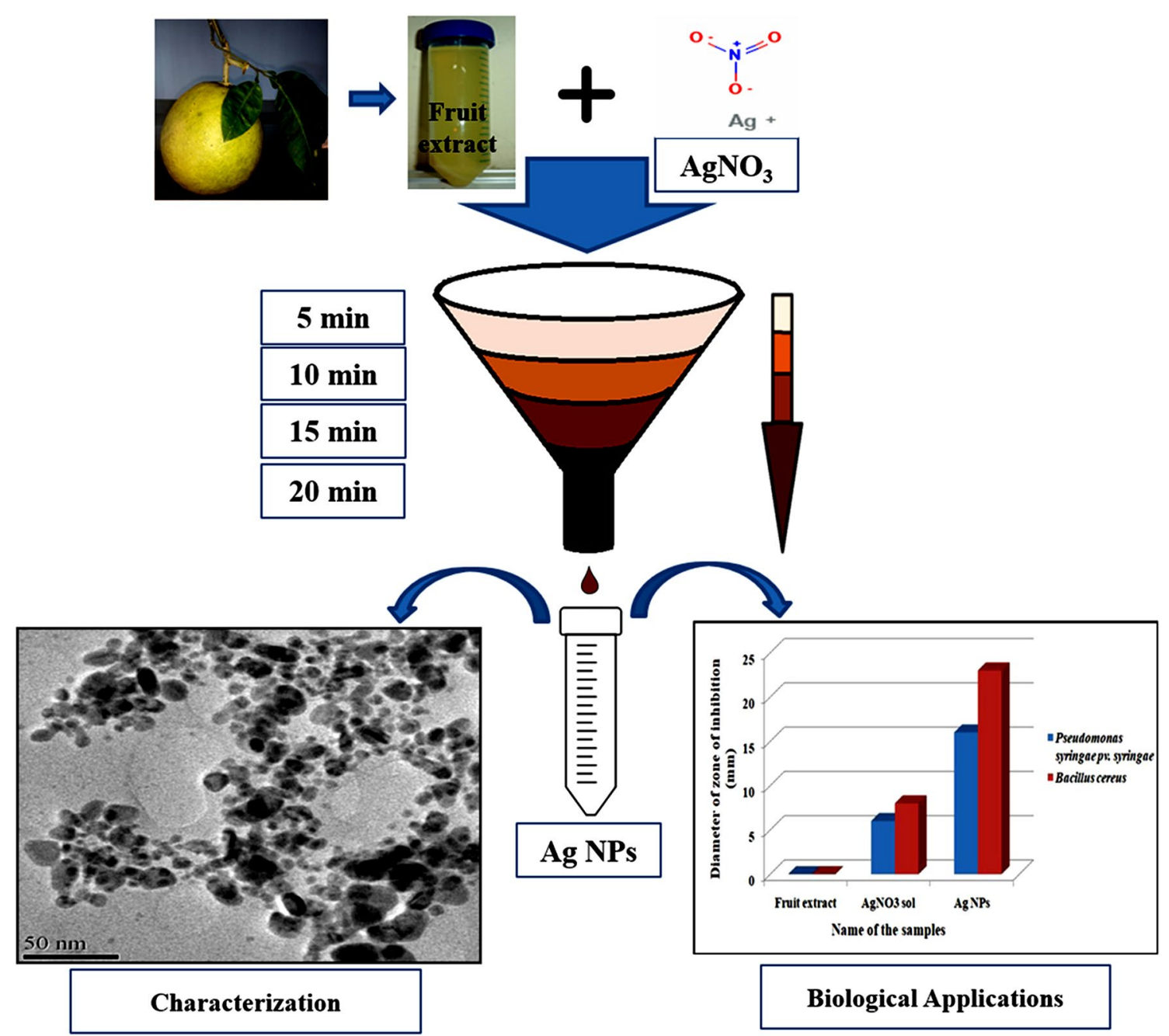

Fig. 1 Overall flowchart of the study 


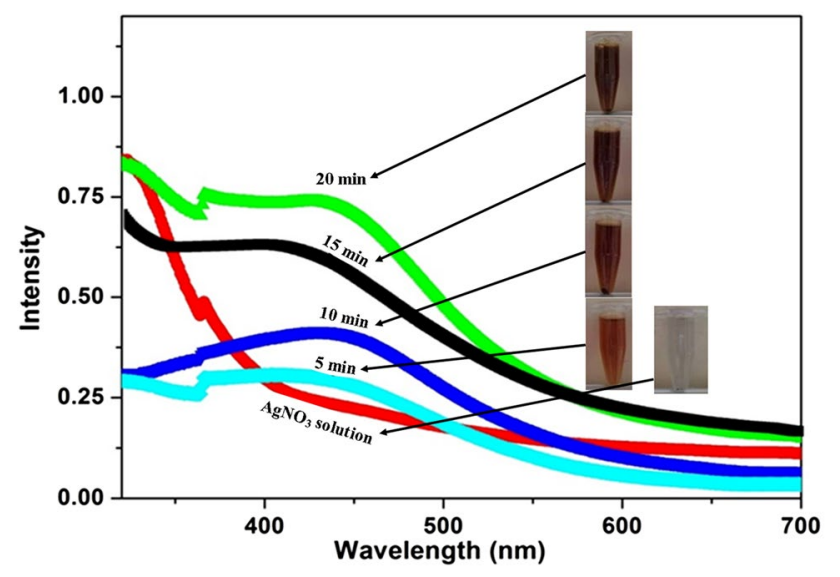

Fig. 2 UV-Vis absorption spectra of the $\mathrm{AgNO}_{3}$ solution and reaction mixture at different time interval

the synthesis and stabilization of Ag NPs [8-11]. Besides, the reaction was carried out in presence of sunlight. Hence it may be hypothesized that the $\mathrm{O}-\mathrm{H}$ group present in the phenolic compound present in the fruit extract may undergo hemolytic cleavage to form hydrogen radical in presence of sunlight irradiation. Due to this, hydrogen radical may transfer its silver ion $\left(\mathrm{Ag}^{+}\right)$to form metallic nanoparticles [27]. On the other hand the oxygen radical may help in the stabilization of AgNPs in the reaction mixture through extended conjugation [27].

\subsection{Structural analysis}

The size and morphology of the Ag NPs as observed in HRTEM is presented in Fig. 3. Most of the Ag NPs are found spherical within the size range of $1-20 \mathrm{~nm}$ diameters. The average diameter of NPs was found to be $11 \pm 3.57 \mathrm{~nm}$ whereas maximum number of Ag NPs was found within the size range of $5-10 \mathrm{~nm}$.

\subsection{XRD analysis}

The X-ray diffraction pattern of the Ag NPs revealed $2 \theta$ values of $39.6^{\circ}, 45.5^{\circ}, 65.6^{\circ}$ and $78.2^{\circ}$ were assigned to (111), (200), (222) and (311) fcc planes (Fig. 4) [28]. No peaks from any other phases were observed suggesting that single-phase Ag with cubic structure nanoparticles has been obtained directly [17]. The intense XRD characteristic peaks clearly indicate that AgNPs synthesized was in crystalline form. The crystallite size of silver nanoparticle is calculated by Scherrer's equation from (111) peak as $10.84 \AA$ A [29].

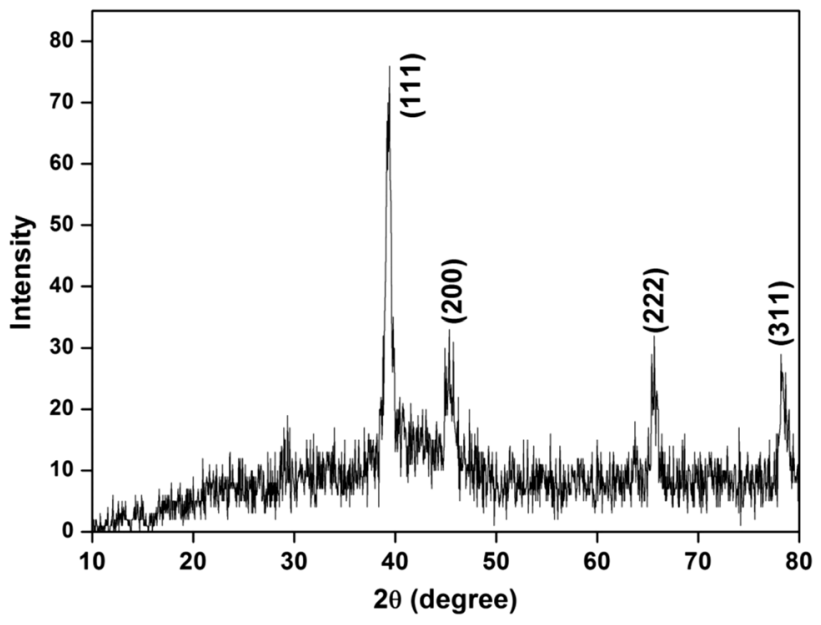

Fig. 4 X-ray diffraction pattern of Ag NPs

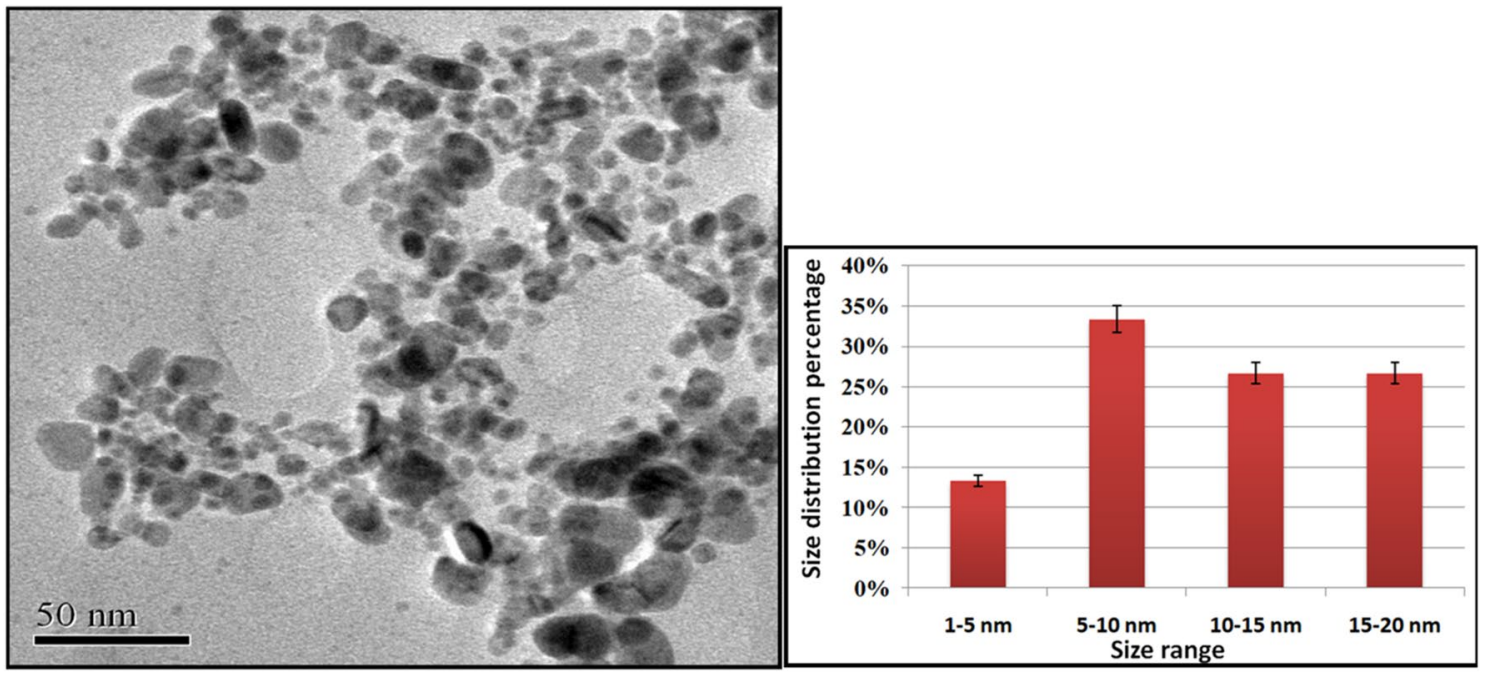

Fig. 3 HRTEM image of the Ag NPs with particle size distribution graph 


\subsection{Antimicrobial assay}

Silver nanoparticles are well reported against various Gram positive and negative microbes but reports are far lagging behind in terms of their efficacy against plant pathogens $[30,31]$. Hence in the present study, antimicrobial assay of AgNPs was carried out against Pseudomonas syringae pv. syringae and Bacillus cereus which are causative agents of most of the plant diseases.

Antimicrobial assay was initially carried out by agar well diffusion method followed by broth dilution assay. Ag NPs showed clear zone of inhibition against both the test organisms. It exerted zone of inhibition of $16 \pm 2$ and $23 \pm 2 \mathrm{~mm}$ respectively against $P$ seudomonas syringae $\mathrm{pv}$. syringae and Bacillus cereus which indicates higher efficacy of the Ag NPs against Bacillus cereus as compared to Pseudomonas syringae pv. syringae (Fig. 5). On the other hand, raw fruit extract showed no antibacterial potential against the strains but $\mathrm{AgNO}_{3}$ showed negligible antibacterial activity against them (Fig. 5). The antimicrobial activity of the green AgNPs was further confirmed by the determination of respective MIC and MBC values against the test organisms by broth dilution assay.

The MIC is the lowest concentration of antimicrobial agents that completely visually inhibits the growth of the microorganisms while MBC is defined as the lowest concentration of antimicrobial agent that kills $99.9 \%$ of the initial bacterial population. For growth inhibitory concentration $(\geq \mathrm{MIC})$, the presence of viable microorganisms was tested and the lowest concentration causing bactericidal effect was reported as MBC. The Ag NPs exerted MIC value of 0.04 and $0.06 \mathrm{mM}$ respectively against $B$. cereus and $P$. syringae pv. syringae. Whereas, $M B C$ value of 0.14 and $0.16 \mathrm{mM}$ were observed against $B$. cereus and $P$ syringae pv. Syringae, respectively (Fig. 6a, b). Both the MIC and $M B C$ values of the Ag NPs against the test organisms were found encouraging as compared to previously reported values $[30,32]$.

\subsection{Cytotoxicity assay}

Mitochondrial dehydrogenase is an enzyme which forms formazan by reacting with MTT and forms purple coloured precipitation indicating presence of viable cells. Higher absorbance at $570 \mathrm{~nm}$ indicates higher percentage of viable cells. From the results, it was observed that the percentage of viable cells decreases gradually with increasing concentration of Ag NPs (Fig. 7). The IC ${ }_{50}$ value of Ag NPs was obtained at a concentration of $160 \mu \mathrm{g} / \mathrm{mL}$ which is just double (i.e., $80 \mu \mathrm{g} / \mathrm{mL}$ ) than that of the concentration of Ag NPs showing MBC values obtained against the plant pathogens. This clearly demonstrates very low to insignificant level of cytotoxicity and hence, advocates its safe use within such limit for human uptake.

\section{Conclusion}

In this study Citrus grandis (L.) Osbeck fruit extract has been tested as a new effective green reducing agent for the synthesis of AgNPs in a simple one step method. The green synthesized AgNPs were found to be stable in nature with an average diameter of $11 \pm 3.57 \mathrm{~nm}$. Further it showed excellent antimicrobial effect against plant pathogens viz., $B$. cereus and $P$. syringae pv. syringae considered in the current study. In addition, the very low to insignificant level of toxicity of the synthesized AgNPs against murine macrophages RAW264.7 cell line points to its future potential for animal model trial.
Fig. 5 Antimicrobial activity of fruit extract, $\mathrm{AgNO}_{3}$ solution and Ag NPs against the pathogens

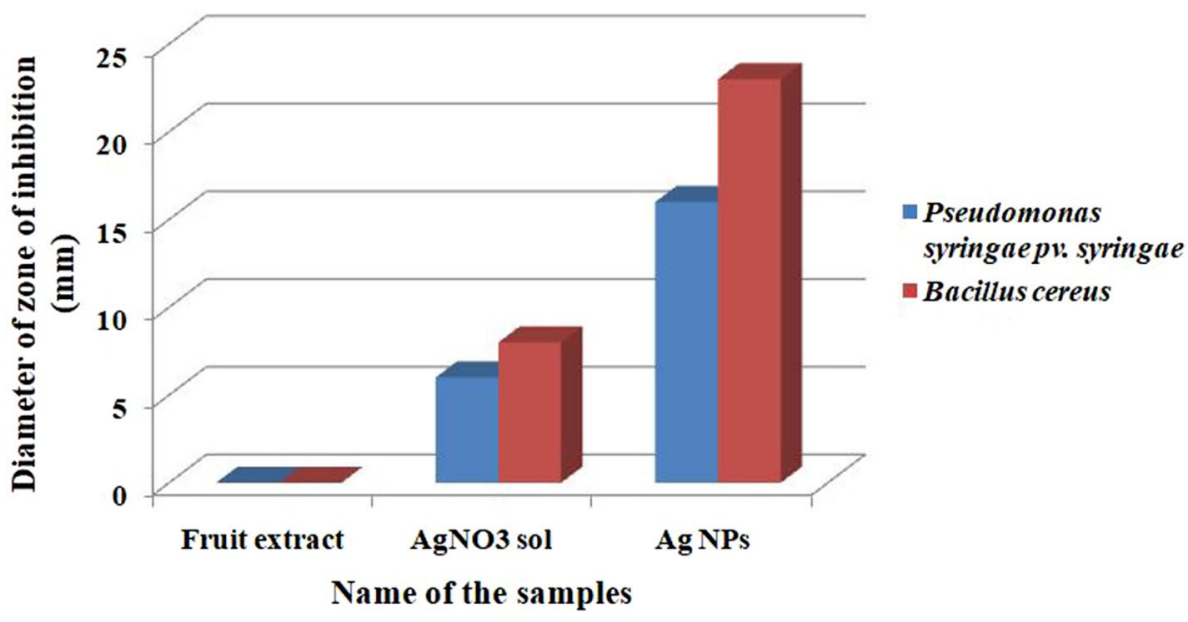

SN Applied Sciences A SPRINGER NATURE journa 
Fig. 6 Growth profile of a Bacillus cereus and $\mathbf{b}$ Pseudomonas syringae pv. syringae in presence of different concentration of Ag NPs at different incubation time
Fig. 7 Cell viability in presence of different concentration of Ag NPs

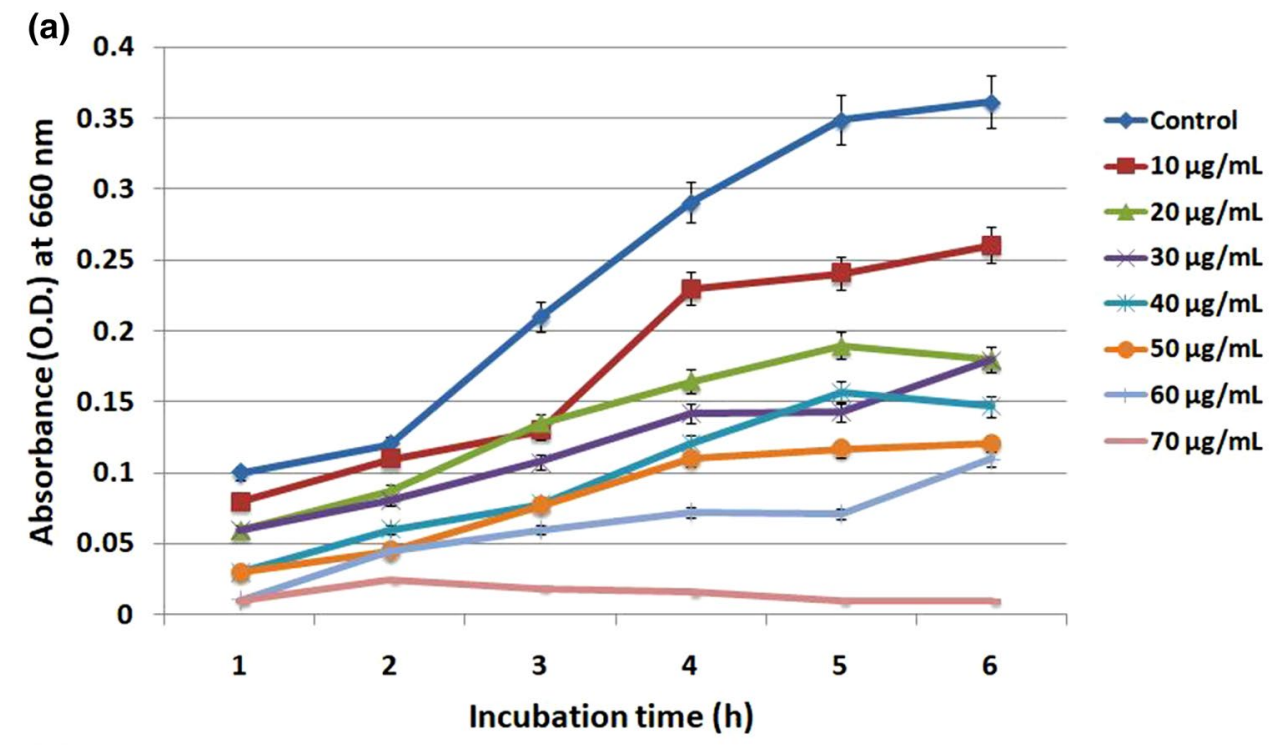

(b)
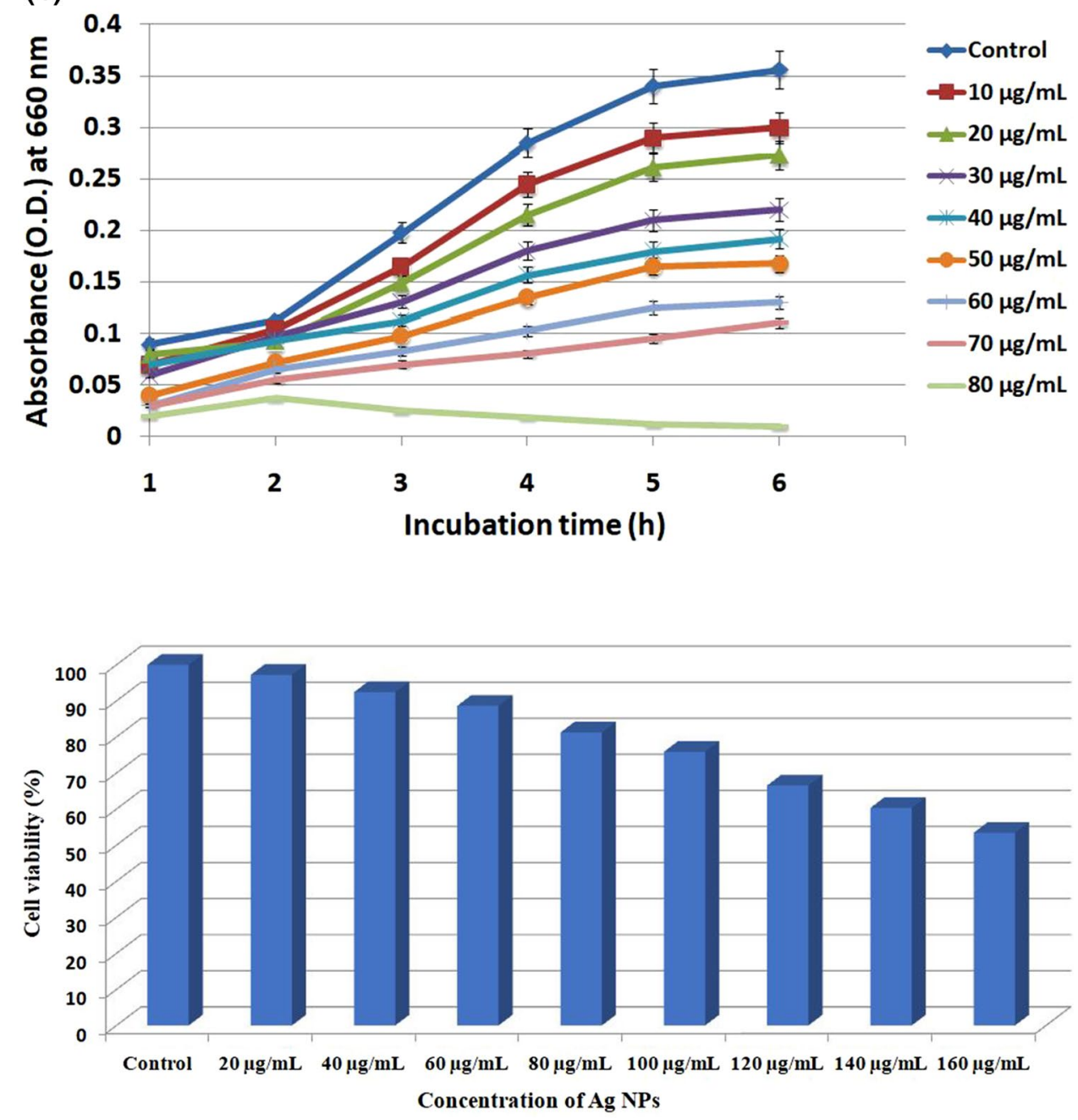


\section{Compliance with ethical standards}

Conflict of interest Authors declare that there is no conflict of interest.

\section{References}

1. Zhang XF, Liu ZG, Shen W, Gurunathan S (2016) Silver nanoparticles: synthesis, characterization, properties, applications, and therapeutic approaches. Int J Mol Sci 17(9)

2. Elegbede JA, Lateef $A$ (2019) Green synthesis of silver (Ag), gold $\mathrm{Au}$ ) and silver-gold ( $\mathrm{Ag}-\mathrm{Au}$ ) alloy nanoparticles: a review on recent advances, trends and biomedical applications. In: Verma DK, Goyal MR, Suleria HAR (eds) Nanotechnology and nanomaterial applications in food, health and biomedical sciences

3. Shah M, Fawcett D, Sharma S, Tripathy SK, Poinern GEJ (2015) Green synthesis of metallic nanoparticles via biological entities. Materials (Basel). 8(11):7278-7308

4. Das RK, Pachapur VL, Lonappan L, Naghdi M, Pulicharla R (2017) Biological synthesis of metallic nanoparticles: plants, animals and microbial aspects. Nanotechnol Environ Eng 2:18

5. Adelere IA, Lateef $A a$ (2016) A novel approach to the green synthesis of metallic nanoparticles: the use of agro-wastes, enzymes and pigments. Nanotechnol Rev 5(6):567-587

6. Lateef A, Ojo SA, Elegbede JAb (2016) The emerging roles of arthropods and their metabolites in the green synthesis of metallic nanoparticles. Nanotechnol Rev 5(6):601-622

7. Akintayo GO, Lateef A, Azeez MA, Asafa TB, Oladipo IC, Badmus JA, Ojo SA, Elegbede JA, Gueguim-Kana EB, Beukes LS, Yekeen TA (2020) Synthesis, bioactivities and cytogenotoxicity of animal fur-mediated silver nanoparticles. IOP Conf Ser Mater Sci Eng 805:012041

8. Kumar D, Lamers H, Singh IP, Ladaniya MS, Sthapit B (2015) Phytochemical evaluation of Pummelo Fruits (Citrus grandis) in India for enhancing marketing opportunities. Indian J Plant Genet Resour 28(1):50-54

9. Ali MY, Rumpa NN, Paul S, Hossen MS, Tanvir EM, Hossan T, Saha M, Alam N, Karim N, Khalil MI, Gan SH (2019) Antioxidant potential, subacute toxicity, and beneficiary effects of methanolic extract of Pomelo (Citrus grandis L. Osbeck) in long evan rats. J Toxicol 10:2529569

10. Lim HK, Yoo ES, Moon JY, Jeon YJ, Cho SK (2006) Antioxidant activity of extracts from Dangyuja (Citrus grandis Osbeck) fruits produced in Jeju Island. Food Sci Biotechnol 15:312-316

11. Marslin G, Siram K, Maqbool Q, Selvakesavan RK, Kruszka D, Kachlicki P, Franklin G (2018) Secondary metabolites in the green synthesis of metallic nanoparticles. Materials 11(6):940

12. Elgorban AM, El-Samawaty AEM, Yassin MA, Sayed SR, Adil SF, Elhindi KM, Bakri M, Khan M (2016) Antifungal silver nanoparticles: synthesis, characterization and biological evaluation. Biotechnol Biotechnol Equip 30(1):56-62

13. Jalal M, Ansari MA, Alzohairy MA, Ali SG, Khan HM, Almatroudi A, Raees K (2018) Biosynthesis of silver nanoparticles from Oropharyngeal Candida glabrata isolates and their antimicrobial activity against clinical strains of bacteria and fungi. Nanomaterials (Basel). 8(8):586

14. Paul S, Mohanram K, Kannan I (2018) Antifungal activity of curcumin-silver nanoparticles against fluconazole-resistant clinical isolates of Candida species. Pharmacol Study 39(3):182-186

15. Akinola PO, Lateef A, Asafab TB, Beukes LS, Hakeem AS, Irshad HM (2020) Multifunctional titanium dioxide nanoparticles biofabricated via phytosynthetic route using extracts of Cola nitida: antimicrobial, dye degradation, antioxidant and anticoagulant activities. Heliyon 6(8):e04610

16. Adebayo EA, lbikunle JB, Oke AM, Lateef A, Azeez MA, Oluwatoyin AO, Oluwa AVA, Blessing OT, Comfort OO, Adekunle OO, Badmus
JA, Asafa TB, Beukes LS, Gueguim-Kana EB, Hakeem AS (2019) Antimicrobial and antioxidant activity of silver, gold and silver-gold alloy nanoparticles phytosynthesized using extract of Opuntia ficus-indica. Rev Adv Mater Sci 58(1):313-326

17. Zhang T, Wang L, Chen Q, Chen C (2014) Cytotoxic potential of silver nanoparticles. Yonsei Med J 55(2):283-291

18. Sharma J, Singh VK, Kumar A, Shankarayan R, Mallubhotla S (2018) Role of silver nanoparticles in treatment of plant diseases. In: Patra J, Das G, Shin HS (eds) Microbial biotechnology. Springer, Singapore

19. Kim SW, Jung JH, Lamsal K, Kim YS, Min JS, Lee YS (2012) Antifungal effects of silver nanoparticles (AgNPs) against various plant pathogenic fungi. Mycobiology 40(1):53-58

20. Iravani S, Korbekandi H, Mirmohammadi SV, Zolfaghari B (2014) Synthesis of silver nanoparticles: chemical, physical and biological methods. Res Pharm Sci 9(6):385-406

21. Prakash A, Sharma S, Ahmad N, Ghosh A, Sinha P (2011) Synthesis of AgNPs by Bacillus cereus bacteria and their antimicrobial potential. J Biomater Nanobiotechnol 2:156-162

22. Gutiérrez B, Cazorla FM, de Vicente A (2019) Pseudomonas syringae pv. syringae associated with mango trees, a particular pathogen within the "Hodgepodge" of the Pseudomonas syringae Complex. Front Plant Sci 8(10):570

23. Xiu FX, Brian K, Sheng YH (2018) Pseudomonas syringae: What it takes to be a pathogen. Nat Rev Microbiol 16(5):316-328

24. Kishore GK, Pande S (2007) Chitin-supplemented foliar application of chitinolytic Bacillus cereus reduces severity of Botrytis gray mold disease in chickpea under controlled conditions. Lett Appl Microbiol 44(1):98-105

25. Borah D, Hazarika M, Tailor P, Silva AR, Chetia B, Singaravelu G, Das $P$ (2018) Starch-templated bio-synthesis of gold nanoflowers for in vitro antimicrobial and anticancer activities. Appl Nanosci 8(3):241-253

26. Lu L, Kobayashi A, Tawa K, Ozaki Y (2006) Silver nanoplates with special shapes: controlled synthesis and their surface plasmon resonance and surface-enhanced Raman scattering properties. Chem Mater 18:4894-4901

27. Brahmachari G, Sarkar S, Ghosh R, Barman S, Mandal NC, Jash SK Banerjee B, Roy R (2014) Sunlight-induced rapid and efficient biogenic synthesis of silver nanoparticles using aqueous leaf extract of Ocimum sanctum Linn. with enhanced antibacterial activity. Org Med Chem Lett 4:18

28. Sun Y, Xia Y (2002) Science. Shape-controlled synthesis of gold and silver nanoparticles. Science 298:2176-2179

29. Patterson AL (1939) The Scherrer formula for X-ray particle size determination. Phys Rev 56:978

30. Qais FA, Shafiq A, Khan HM, Husain FM, Khan RA, Alenazi B, Alsalme A (2019) Antibacterial effect of silver nanoparticles synthesized using Murrayakoenigii (L.) against multidrug-resistant pathogens. BioinorgChem Appl 1:4649506

31. Ramalingam B, Parandhaman T, Das SK (2016) Antibacterial effects of biosynthesized silver nanoparticles on surface ultrastructure and nanomechanical properties of gram-negative bacteria viz., Escherichia coli and Pseudomonas aeruginosa. ACS Appl Mater Interfaces 8(7):4963-4976

32. González E, Enrique C, Cervantes JAG, Rodríguez VA, Peralta LZM, Gonzalez MTT, Castro EDB, Salazar EMS, Morales RMC, Soto DIR, González FMT, Rosales C, Cruz RV, Ramírez JRM (2018) In vivo antimicrobial activity of silver nanoparticles produced via a green chemistry synthesis using Acacia rigidula as a reducing and capping agent. Int J Nanomed 13:2349

Publisher's Note Springer Nature remains neutral with regard to jurisdictional claims in published maps and institutional affiliations. 